\title{
Physicochemical properties of spray-dried rice flour with Lactobacillus plantarum CGKW3
}

\author{
Hye-Mi Park ${ }^{1}$, Dae-Hoon Lee ${ }^{1}$, Yoo-Seok Jeong ${ }^{2}$, Hee-Kyoung Jung ${ }^{2}$, \\ Jae-Gon $\mathrm{Cho}^{3}$, Joo-Heon Hong ${ }^{1 *}$ \\ ${ }^{1}$ Department of Food Science and Technology, Catholic University of Daegu, Gyeongsan 712-702, Korea \\ ${ }^{2}$ Biohealth Convergence Center, Daegu Technopark, Daegu 704-801, Korea \\ ${ }^{3}$ Young Poong Co., Daegu 704-801, Korea
}

\section{분무건조공정을 이용한 유산균포집 미분의 제조 및 물리화학적 특성}

\author{
박혜미 $^{1} \cdot$ 이대훈 $^{1} \cdot$ 정유석 ${ }^{2} \cdot$ 정희경 $^{2} \cdot$ 조재 곤 ${ }^{3} \cdot$ 홍주헌 $^{1 *}$ \\ ${ }^{1}$ 대구가톨릭대학교 식품공학전공, ${ }^{2}$ (재)대구테크노파크 바이오헬스융합센터, \\ 3농업회사법인 (주)영풍
}

\begin{abstract}
The physicochemical properties of spray-dried rice flour with Lactobacillus plantarum CGKW3 were investigated. Amylose and damaged starch contents of spray-dried rice flour (S10, S20, S30, and S50) with $L$. plantarum CGKW3 were $14.18 \sim 17.75 \%$ and $24.65 \sim 34.08 \%$, respectively. The particle size of spray-dried rice flour was $82.28 \sim 131.17$ $\mu \mathrm{m}$. The rice flour with $L$. plantarum CGKW3 showed a good powder flowability. The water absorption and water solubility of spray-dried rice flour were 1.96 2.13 and 9.91 21.95\%, respectively. Thermal properties measured by differential scanning calorimeter revealed that the enthalpy $(\triangle H)$ for starch gelatinization were highest in the rice flour (S50) with $L$. plantarum CGKW3. When compared, the viable cell number of spray-dried rice flour were found to be in the following order: S10 $(5.78 \log$ CFU/g) $<$ S20 $(6.38 \log$ CFU/g) $<$ S30 (6.69 log CFU/g) $<$ S50 (7.11 $\log \mathrm{CFU} / \mathrm{g})$. The survaival rate of $L$. plantarum CGKW3 was $60.02-73.85 \%$, which reflected the improvement in the quality of rice flour with an increase in treatment concentration. Based on our results, spray-dried rice flour with $L$. plantarum CGKW3 could be used in various types of rice foods.
\end{abstract}

Key words : rice flour, Lactobacillus plantarum CGKW3, spray drying, encapsulation, physicochemical properties

\section{서 론}

유산균(lactic acid bacteria, LAB)은 당을 발효해서 다량 의 젖산을 생산하는 세균으로 유산음료, 치즈, 된장, 김치, 탁주 및 젓갈 등 전통적인 발효식품의 제조에 이용되어 식품의 보존성을 높여온 경제적으로 중요한 의미를 지닌

*Corresponding author. E-mail : jhhong@cu.ac.kr Phone : 82-53-850-3218, Fax: 82-53-850-3218

Received 24 March 2015; Revised 8 May 2015; Accepted 23 May 2015.

Copyright (c) The Korean Society of Food Preservation. All rights reserved.
미생물이다(1). 전세계적으로 이용되고 있는 주요 유산균 종은 Lactobacillus 속으로 장내에 정상 세균총의 유지, 면역 증강 작용 및 아토피 피부염 치료 효능 등의 기능이 보고되 고 있다 $(2,3)$. 사람에게 투여되어 여러 가지 건강 증진 효과 를 가져올 수 있는 유산균을 프로바이오틱스(probiotics)라 부르며, 일반적으로 이들 프로바이오틱스의 효능은 장까지 도달한 살아있는 유산균에 달려 있다(4). 그러나 대부분의 프로바이오틱스는 까다로운 미생물로 다양한 환경조건에 매우 민감하여 제조, 유통 및 저장단계에서 뿐만 아니라 항생제, 노화, 스트레스와 식이 등으로 인해 생존율에 크게 영향을 받게 되어 활성이 감소하여(4-6), 안정성의 개선이 필요하다고 사료된다. 
식품 분야에서 많이 활용되고 있는 캡슐화(encapsulation) 는 식품소재의 산화방지 및 보존성 향상, 변화하기 쉬운 식품소재의 안정화, 불필요한 냄새의 차단, 액상식품의 고 형화, 식품소재의 방출속도 조절, 제조공정의 개선 및 물성 향상 등의 장점을 가지고 있다 $(7,8)$. 캡슐화에 있어 핵물질 (core materials)의 특성과 사용될 목적에 따라 다양한 중합 체가 피복물질(wall materials)로 이용되고 있는데 $(9,10)$, maltodextrin, cyclodextrin, modified lipophilic starch 및 gum 류 등과 같은 탄수화물이 주로 사용되고 있다 $(11,12)$. 전분 에 핵물질을 캡슐화시키는 원리로는 모세관의 형성 (formation of capillary), 흡수(sorption) 및 포집화합물의 형 성(inclusion complexes) 등으로 보고되고 있다(13).

쌀의 일반 영양성분은 쌀의 품종, 재배지역 등에 따라 다소 차이는 있으나 백미의 경우 전분이 75 80\%, 단백질이 6 8\%, 지방, 섬유질 및 회분이 각각 $1 \sim 3 \%$ 정도 함유하고 있다(14). 쌀의 주요 성분인 전분은 구조가 서로 다른 아밀 로오즈와 아밀로펙틴으로 구성되어 있으며 아밀로오즈 함 량의 차이에 따라 쌀의 호화 및 노화 특성 등 품질에 많은 차이를 보이고(15), 쌀가공품의 품질은 쌀가루의 입도크기 및 분포, 전분손상, 호화특성 등의 변화에 영향을 받는다 (16-18). 쌀시장 개방, 소비자 기호도 및 다양성의 변화 등으 로 인하여 1 인당 연간 쌀 소비량은 2005 년 $80.7 \mathrm{~kg}$ 에서 2014년 $65.1 \mathrm{~kg}$ 으로 최근 10년간 지속적으로 감소하는 추세 를 보이고 있다(19). 이에 쌀의 소비를 증가시키기 위해 주식뿐만이 아닌 쌀 가공제품 개발 및 다양화를 위한 노력 이 이루어지고 있다(20). 국내 쌀가공에 관한 연구로는 건식 과 습식, 열처리, 건조공정 및 제분조건 등을 달리한 쌀가루 제조 $(21,22)$ 가 주를 이루었으나 근래에는 떡류(23), 쌀식빵 (24), 국수(25), 죽류(26) 및 수산가공 식품과 병용한 식품개 발(27)에 대한 연구 등이 보고되고 있다.

본 연구에서는 국내 쌀의 소비를 증가시키고 쌀 가공제 품 개발시 기능성 및 가공적성이 향상된 미분을 제공하고자 분무건조공정에 의해 유산균을 포집한 미분을 제조하였으 며, 제조된 유산균포집 미분의 물리화학적 특성 및 유산균 생존율을 조사하여 쌀 가공제품 개발시 가공적성 및 품질개 선을 위한 기초 자료로 활용하고자 하였다.

\section{재료 및 방법}

\section{실험재료}

본 실험에 사용된 미분은 국내산으로 2014년 11월 대구 소재의 농업회사법인 (주)영풍에서 제공받은 것을 $60 \mathrm{mesh}$ 표준망체(0.250 mm, Chunggye, Seoul, Korea)에 통과시킨 뒤, $121^{\circ} \mathrm{C}, 1.2$ 기압에서 15 분동안 처리한 다음 유산균포집 을 위한 피복물질로 사용하였다. 유산균주는 대구가톨릭대 학교 기능성식품학연구실에서 김치로부터 분리한 Lactobacillus plantarum CGKW3(KACC92075P)를 사용하였으며, MRS 배지에 액체 종균 $3 \%$ 를 접종하고 $37^{\circ} \mathrm{C}$ 에서 24 시간 정치 배양한 다음 사용하였다. 24시간 배양한 유산균 배양액의 유산균수는 $9.63 \log \mathrm{CFU} / \mathrm{mL}$ 로 나타났으며, $\mathrm{pH}$ 및 산도는 각각 $3.87,1.56 \%$ 이었다.

\section{유산균포집 미분의 제조}

분무건조에 의한 유산균포집 미분의 제조는 미분을 유산 균 배양액 대비 각각 $10 \%, 20 \%, 30 \%$ 및 $50 \%(\mathrm{w} / \mathrm{v})$ 를 첨가하 여 교반한 다음 아토마이져(atomizer)가 장착된 분무건조기 (KL-8, Seogang engineering Co., Ltd., Cheonan, Korea)를 이용하여 주입 온도 $160^{\circ} \mathrm{C}$, 방출 온도 $100^{\circ} \mathrm{C}$ 로 설정하였고, 분무속도는 $17,000 \mathrm{rpm}$ 에서 시료공급속도는 $12 \mathrm{~mL} / \mathrm{min}$ 의 조건으로 제조하였으며, $-70^{\circ} \mathrm{C}$ 이하의 암소에 보관하면서 분석용 시료로 사용하였다. 대조구로는 증류수에 미분을 첨가하여 교반한 뒤 분무건조한 분말을 사용하였다.

\section{아밀로오즈함량 측정}

아밀로오즈함량은 Williams 등(28)의 방법에 의해 측정 하였다. 시료 $0.1 \mathrm{~g}$ 에 $95 \%$ ethanol $1 \mathrm{~mL}$ 와 $1 \mathrm{~N} \mathrm{NaOH}$ $9 \mathrm{~mL}$ 를 첨가하여 분산시키고 $100^{\circ} \mathrm{C}$ 진탕 항온수조(BS-31, Jeio tech Co., Ltd., Seoul, Korea)에 넣어 10 분 동안 반응시켰 다. 반응시킨 후 반응용액 $5 \mathrm{~mL}$ 를 취하고 $1 \mathrm{~N}$ acetic acid $1 \mathrm{~mL}$ 와 iodine-potassium iodine 용액(w/v, Duksan pure chemicals Co., Ltd., Ansan, Korea) $2 \mathrm{~mL}$ 를 첨가한 후 증류수 를 이용하여 $100 \mathrm{~mL}$ 가 되도록 정용하였으며, 30 분 동안 방치한 다음 분광광도계(Ultraspec-2100pro, Amersham Co., Uppsala, Sweden)를 이용하여 $620 \mathrm{~nm}$ 에서 흡광도를 측정하 였다. 아밀로오즈함량은 감자에서 분리된 아밀로오즈 (Sigma-Aldrich Co., St. Louis, MO, USA)를 정량하여 작성 한 표준곡선으로부터 계산하였다.

\section{손상전분함량 측정}

손상전분함량은 Boyaci 등(29)의 방법에 의해 측정하였 다. 시료 $9 \mathrm{~g}$ 을 $100 \mathrm{~mL}$ 정용플라스크에 넣고, a-amylase 용액(Aspergillus oryzae 125,000 unit in $450 \mathrm{~mL}$ acetate buffer, Sigma-Aldrich Co., St. Louis, MO, USA) $45 \mathrm{~mL}$ 를 첨가하여 유리막대로 잘 혼합한 다음 $30^{\circ} \mathrm{C}$ 진탕 항온수조 (BS-31, Jeio tech Co.)에 넣어 25분 동안 반응시켰다. 이 용액에 $3.68 \mathrm{~N}$ sulfuric acid(Duksan pure chemicals Co., Ltd.) $3 \mathrm{~mL}$ 와 $12 \%$ sodium tungstate 용액(w/v, Duksan pure chemicals Co., Ltd.) $2 \mathrm{~mL}$ 를 첨가하여 잘 혼합한 후 2 분간 정치시켜 Whatman No. 4 여과지로 여과한 다음 굴절당도 계(N-1E, Atago Co., Ltd., Tokyo, Japan)를 이용하여 Brix를 측정하여 전분손상도 값을 아래와 같이 계산하였다.

$$
\text { 손상전분함량 }(\%)=\frac{\left(B_{2}-B_{1}\right) \times V}{M} \times F
$$


$\mathrm{B}_{1}=$ Brix value of blank filtrate

$\mathrm{B}_{2}=$ Brix value of sample filtrate

$\mathrm{V}=$ Volume of slurry

$\mathbf{M}=$ Sample weight

$\mathrm{F}=$ Conversion factor $=1.64$

\section{입자크기 및 입자표면구조 분석}

입자크기는 레이저입도분석기(LS-13-320, Beckman coulter, Fullerton, CA, USA)를 이용하여 시료를 isopropyl alcohol에 분산시켜 측정하였다. 입자표면구조는 각 시료에 gold ion coating한 후 주사형 전자현미경(S-4800, Hitachi high-Technologies Co., Tokyo, Japan)을 이용하였으며, 전자 현미경을 이용한 관찰은 $3.0 \mathrm{kV}$ 에서 1,000 배 비율로 하였다.

\section{수분함량 측정}

수분함량은 시료 $0.5 \mathrm{~g}$ 을 페트리디쉬에 담아 적외선 수분 측정기(MB-45, Moisture analyzer, INC., Ohaus, USA)를 이 용하여 $105^{\circ} \mathrm{C}$ 에서 분말의 수분함량이 항량에 도달할 때까 지 건조하여 측정하였다.

\section{수분흡수지수(WAI) 및 수분용해지수(WSI) 측정}

수분흡수지수(water absorption index, WAI) 및 수분용해 지수(water solubility index, WSI)는 phillips(30)의 방법을 변형하여 측정하였다. 시료 $0.5 \mathrm{~g}$ 에 $20 \mathrm{~mL}$ 증류수를 첨가하 여 $3,000 \mathrm{rpm}$ 에서 20 분간 원심분리 한 후 침전물은 수분흡 수지수로 사용하였으며, 상등액은 미리 무게를 구한 수기 에 분리하여 $105^{\circ} \mathrm{C}$ 에서 4 시간 동안 건조시킨 고형분을 수분 용해지수로 사용하여 아래와 같이 계산하였다.

$$
\begin{aligned}
& \text { 수분흡수지수(WAI) }=\frac{\text { 침전물의 양 }}{\text { 시료의 양 }} \\
& \text { 수분용해지수(WSI, \%) }=\frac{\text { 상등액고형분의 양 }}{\text { 시료의 양 }} \times 100
\end{aligned}
$$

\section{시차주사열량계에 의한 호화 특성 분석}

호화 특성은 $\mathrm{Kim}$ 등(31)의 방법에 의해 시차주사열량계 (differential scanning calorimeter, DSC-60, Shimadzu Co., Kyoto, Japan)를 이용하여 분석하였다. DSC thermogram은 $10^{\circ} \mathrm{C}$ 부터 $250^{\circ} \mathrm{C}$ 까지 $10^{\circ} \mathrm{C} / \mathrm{min}$ 의 속도로 가열하여 얻은 후 호화개시온도(To, gelatinization onset temperature), 최대호 화온도(Tp, gelatinization peak temperature), 호화종결온도 (Tc, gelatinization completion temperature)와 흡열엔탈피( $\Delta$ $\mathrm{H}$, gelatinization enthalpy)를 Universal analysis 2000 Program(4.5A, TA Instruments, Newcastle, DE, USA)에 의 해 계산하였다.

\section{생균수 측정}

생균수는 시료 $1 \mathrm{~g}$ 에 $0.85 \%$ sodium chloride 용액(w/v,
Duksan pure chemicals Co., Ltd.) $9 \mathrm{~mL}$ 를 첨가하여 10 배 희석법으로 희석한 다음 각각의 희석액 $100 \mu \mathrm{L}$ 를 $1.5 \%$ agar(Sigma-Aldrich Co., St. Louis, MO, USA)가 첨가 된 $\mathrm{MRS}$ 배지에 접종하여 평판 측정법으로 측정하였다. 각각 의 plate는 $37^{\circ} \mathrm{C}$ 에서 24 시간 배양한 다음 형성된 colony 수를 계측하고, colony에 희석배수를 곱하여 시료 $\mathrm{g}$ 당 $\mathrm{CFU}$ (colony forming unit)로 나타내었다.

\section{통계처리}

실험결과는 3회 반복으로 행하여 평균표준편차로 나타 내었고 SPSS(19.0, SPSS Inc., Chicago, IL, USA)를 이용하여 분산분석(ANOVA)을 실시하였으며, 각 측정 평균값의 유의 성 $(\mathrm{p}<0.05)$ 은 Duncan's multiple range test로 검정하였다.

\section{결과 및 고찰}

아밀로오즈함량, 손상전분함량, 입자크기 및 입자표면구조 유산균포집 미분의 아밀로오즈함량, 손상전분함량, 입 자크기 및 입자표면구조는 Table 1, Fig. 1 및 Fig. 2와 같다. 쌀은 아밀로오즈함량에 따라서 저 아밀로오즈(10 20\%), 중간 아밀로오즈(20 25\%) 및 고 아밀로오즈( $25 \%<$ 로 분류 된다(32). 아밀로오즈함량은 유산균을 첨가하지 않은 미분 의 경우 $19.91 \%$ 로 가장 높은 함량을 나타내었으며, 유산균 포집 미분에서 14.18 17.75\%로 낮은 함량을 나타내었다 (Table 1). 일반적으로 아밀로오즈함량이 $22 \%$ 이상인 쌀이 빵이나 국수 등의 가공용에 적합한 것으로 간주되는데(25), 유산균포집 미분에서 미분 첨가량이 $10 \%$ 에서 $50 \%$ 로 높아 질수록 아밀로오즈함량이 각각 $14.18 \%, 15.82 \%, 16.92 \%$ 및 $17.75 \%$ 로 높아지는 경향을 나타내어 쌀 가공제품 개발 에 있어 혼합 소재로 적용이 가능할 것으로 사료된다. 손상 전분함량은 유산균을 첨가하지 않은 미분(38.95\%)에 비하 여 유산균포집 미분이 24.65 34.08\%로 유의적으로 낮은 함량을 나타내었으며, 미분 첨가량이 높아질수록 손상전분 함량이 낮아지는 것을 확인하였다. 입자크기의 경우 유산 균을 첨가하지 않은 미분에서 $77.21 \mu \mathrm{m}$ 로 가장 작았으며, 유산균포집 미분은 82.28 131.17 $\mu \mathrm{m}$ 로 유의적으로 큰 입자 크기를 나타내었으며, 미분 첨가량이 $50 \%$ 일 때 $131.17 \mu \mathrm{m}$ 로 가장 컸다. 특히 분무건조공정에 의한 미분 제조시 Fig. 1 과 같이 입자 크기가 단일 포물선 형태로 분포함을 확인하 였으며, 이로 인해 균일한 입자크기를 가지는 분말의 제조 가 가능할 것으로 판단된다. Park 등(33)의 연구에 따르면 초미세 쌀가루로 입자크기가 작을수록 전분손상도가 증가 한다고 보고하였는데, 본 연구의 유산균포집 미분에서도 유사한 경향을 나타냄을 확인하였다. 유산균포집 미분의 입자표면구조를 측정한 결과, 미분 첨가량이 높아질수록 전반적으로 구형의 모양을 보여주어 분말 흐름성이 양호할 
것으로 사료된다(Fig. 2). 특히 미분 첨가량 $30 \%$ 및 $50 \%$ 의 유산균포집 미분의 경우 입자표면에 굴곡이 적고 조밀한 구형을 나타냄을 확인하였는데, 이로 인해 내부 물질인 유 산균을 포집하는데 유리할 것으로 판단되었다.

Table 1. Amylose contents, damaged starch contents, and particle size of rice flour that included Lactobacillus plantarum CGKW3 by a spray-drying process

\begin{tabular}{cccc}
\hline Samples ${ }^{1)}$ & $\begin{array}{c}\text { Amylose content } \\
(\%)\end{array}$ & $\begin{array}{c}\text { Damaged starch } \\
\text { content }(\%)\end{array}$ & $\begin{array}{c}\text { Particle size } \\
(\mu \mathrm{m})\end{array}$ \\
\hline Non & $19.91 \pm 0.28^{\mathrm{a} 2)}$ & $38.95 \pm 1.39^{\mathrm{a}}$ & $77.21 \pm 0.18^{\mathrm{e}}$ \\
S10 & $14.18 \pm 0.36^{\mathrm{e}}$ & $34.08 \pm 0.53^{\mathrm{b}}$ & $82.28 \pm 0.57^{\mathrm{d}}$ \\
S20 & $15.82 \pm 0.26^{\mathrm{d}}$ & $33.78 \pm 0.91^{\mathrm{b}}$ & $84.24 \pm 0.12^{\mathrm{c}}$ \\
S30 & $16.92 \pm 0.45^{\mathrm{c}}$ & $33.47 \pm 1.05^{\mathrm{b}}$ & $85.54 \pm 0.11^{\mathrm{b}}$ \\
S50 & $17.75 \pm 0.09^{\mathrm{b}}$ & $24.65 \pm 1.58^{\mathrm{c}}$ & $131.17 \pm 1.29^{\mathrm{a}}$ \\
\hline
\end{tabular}

${ }^{11}$ Non, spray-dried powder of $100 \%$ rice flour; S10, spray-dried powder of $10 \%$ rice flour included $L$ plantarum CGKW3; S20, spray-dried powder of $20 \%$ rice flour included $L$ plantarum CGKW3; S30, spray-dried powder of 30\% rice flour included $L$ plantarum CGKW3; S50, spray-dried powder of $50 \%$ rice flour included L. plantarum CGKW3.

${ }^{2)}$ Means $\pm \mathrm{SD}(\mathrm{n}=3)$ within each column (a-e) followed by the same letter are not significantly different $(\mathrm{p}<0.05)$.

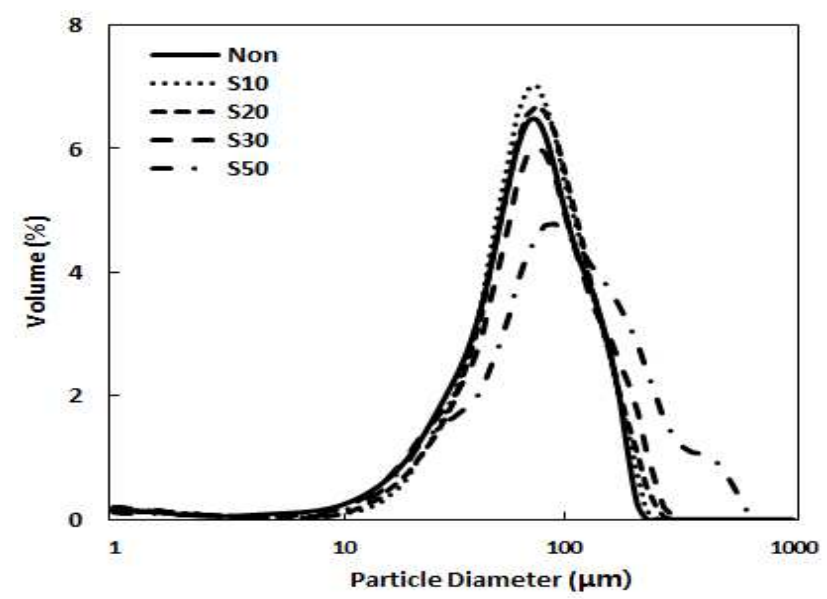

Fig. 1. Particle size distribution of rice flour included Lactobacillus plantarum CGKW3 by spray-drying process.

Non, spray-dried powder of $100 \%$ rice flour; S10, spray-dried powder of $10 \%$ rice flour included $L$ plantarum CGKW3; S20, spray-dried powder of $20 \%$ rice flour included $L$. plantarum CGKW3; S30, spray-dried powder of $30 \%$ rice flour included $L$ plantarum CGKW3; S50, spray-dried powder of 50\% rice flour included $L$. plantarum CGKW3.
수분함량, 수분홉수지수(WAI) 및 수분용해지수(WSI)

유산균포집 미분의 수분함량, 수분흡수지수 및 수분용해 지수는 Table 2와 같다. 수분함량은 유산균을 첨가하지 않 은 미분의 경우 $3.34 \%$ 로 가장 높은 함량을 나타내었으며, 유산균포집 미분에서 2.32 2.62\%로 낮은 함량을 나타내었 으나 미분 첨가량에 따라 유의적인 차이는 나타나지 않았 다. 일반적으로 미분의 수분함량은 작물의 수확시기, 보관 기간 및 보관조건에 따라 많은 영향을 미치는데, Lee(20)의 국내 쌀품종에 따른 쌀가루 수분함량을 측정한 결과 7.19 13.89\%로 나타내었으며, Jeong 등(34)의 분무건조 탁 주분말의 수분함량을 측정한 결과 $6.64 \%$ 로 나타나 본 연구 의 유산균포집 미분이 낮은 수분함량을 나타냄을 확인할 수 있었다. 수분흡수지수는 유산균을 첨가하지 않은 미분 (2.39)에 비하여 유산균포집 미분이 1.96 2.13으로 유의적 으로 낮은 지수를 나타내었으며, 미분 첨가량이 $10 \%$ 에서 $50 \%$ 로 증가할수록 각각 $1.96,1.96,2.05$ 및 2.13으로 높아지 는 경향을 나타내었다. Han 등(32)은 품종이 다른 쌀가루의 수분 흡수력을 측정한 결과 쌀알의 경도보다 아밀로오즈함 량이 높은 품종의 경우 수분흡수력이 더 높았다고 보고하였 는데, 본 연구에서도 아밀로오즈함량이 높을수록 수분흡수 력이 높게 나타나 유사한 경향을 나타내었다. 수분용해지 수는 유산균을 첨가하지 않은 미분에서 $0.68 \%$ 로 가장 낮은 지수를 나타내었으며 유산균포집 미분에서 9.91 21.95\%로

Table 2. Moisture contents, water absorption index (WAI), and water solubility index (WSI) of rice flour that included Lactobacillus plantarum CGKW3 by a spray-drying process

\begin{tabular}{cccc}
\hline Samples $)^{1)}$ & $\begin{array}{c}\text { Moisture content } \\
(\%)\end{array}$ & WAI & $\begin{array}{c}\text { WSI } \\
(\%)\end{array}$ \\
\hline Non & $3.34 \pm 0.41^{\mathrm{a} 2)}$ & $2.39 \pm 0.03^{\mathrm{a} 2)}$ & $0.68 \pm 0.04^{\mathrm{d}}$ \\
S10 & $2.42 \pm 0.47^{\mathrm{b}}$ & $1.96 \pm 0.03^{\mathrm{d}}$ & $21.95 \pm 0.17^{\mathrm{a}}$ \\
S20 & $2.62 \pm 0.42^{\mathrm{b}}$ & $1.96 \pm 0.04^{\mathrm{d}}$ & $18.49 \pm 1.53^{\mathrm{b}}$ \\
S30 & $2.32 \pm 0.26^{\mathrm{b}}$ & $2.05 \pm 0.02^{\mathrm{c}}$ & $10.95 \pm 0.53^{\mathrm{c}}$ \\
S50 & $2.48 \pm 0.37^{\mathrm{b}}$ & $2.13 \pm 0.03^{\mathrm{b}}$ & $9.91 \pm 0.27^{\mathrm{c}}$ \\
\hline
\end{tabular}

${ }^{1)}$ Non, spray-dried powder of $100 \%$ rice flour; S10, spray-dried powder of $10 \%$ rice flour included $L$ plantarum CGKW3; S20, spray-dried powder of $20 \%$ rice flour included L plantarum CGKW3; S30, spray-dried powder of 30\% rice flour included $L$ plantarum CGKW3; S50, spray-dried powder of 50\% rice flour included L. plantarum CGKW3.

${ }^{2)}$ Means \pm SD (n=3) within each column (a-d) followed by the same letter are not significantly different $(\mathrm{p}<0.05)$.

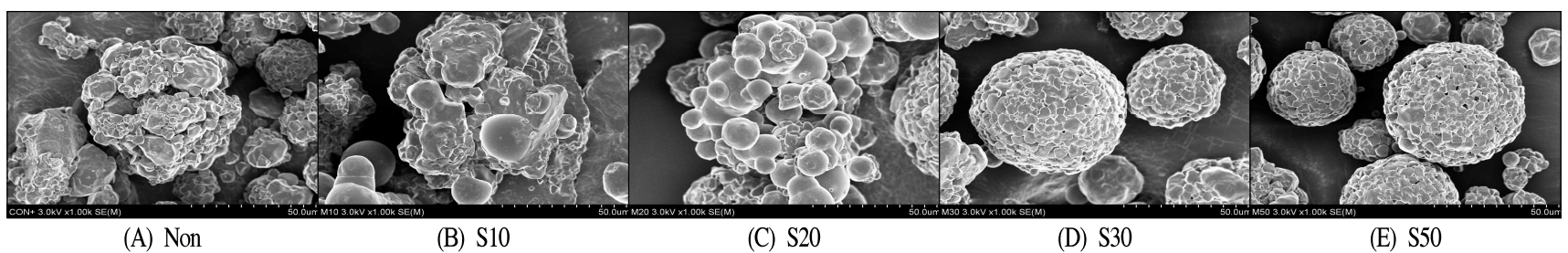

Fig. 2. Scanning electron microscope $(3.0 \mathrm{kV} \times 1,000)$ of rice flour that included Lactobacillus plantarum CGKW3 by a spray-drying process. Non, spray-dried powder of $100 \%$ rice flour; S10, spray-dried powder of $10 \%$ rice flour included L plantarum CGKW3; S20, spray-dried powder of $20 \%$ rice flour included $L$. plantarum CGKW3; S30, spray-dried powder of 30\% rice flour included $L$. plantarum CGKW3; S50, spray-dried powder of $50 \%$ rice flour included $L$ plantarum CGKW3. 
높은 용해지수를 나타내었다. 특히 유산균포집 미분에서 미분의 첨가량이 높아질수록 수분용해지수는 유의적으로 낮아졌으며, 아밀로오즈함량이 높아질수록 수분용해지수 는 낮아져 수분흡수지수와는 다른 경향을 나타내었다. 이 에 유산균포집 미분의 경우 유산균을 첨가하지 않은 미분보 다 유의적으로 흡습성이 낮고 용해성이 양호한 분말을 얻을 수 있을 것이라 판단된다.

\section{시차주사열량계에 의한 호화특성}

유산균포집 미분의 시차주사열량계(DSC)에 의한 호화 특성은 Table 3 과 같다. 호화개시온도(To)는 모든 시료에서 차이를 나타내지 않고 유사한 결과를 나타내었으나, 최대 호화온도(Tp), 호화종결온도( $\mathrm{Tc})$ 및 호화엔탈피 $(\triangle \mathrm{H})$ 는 유 산균포집 미분에서 미분의 첨가량이 높아질수록 높은 온도 및 엔탈피를 나타냄을 확인할 수 있었다. 유산균포집 미분 의 호화개시온도(To)는 $24.47 \sim 25.22^{\circ} \mathrm{C}$ 범위이고, 최대호화 온도는 $89.26 ~ 103.77^{\circ} \mathrm{C}$, 호화종결온도는 $168.29 \sim 180.80^{\circ} \mathrm{C}$ 로 측정되었다. Choi(35)는 유색미의 시차주사열량계에 의 한 열 특성 분석 결과 호화개시온도가 $70 ~ 71^{\circ} \mathrm{C}$ 범위로 높아 낮은 취반 특성을 나타낸다고 보고하였는데, 본 연구의 유 산균포집 미분의 경우 낮은 호화개시온도를 나타내어 취반 특성이 높을 것으로 사료된다. Ko와 Park(36)은 일부 곡류 의 전분 구조 내에 존재하고 있는 amylose-lipid complex의 용융으로 인한 호화종결온도(Tc)가 상승한다고 보고하였 는데, 본 연구에서는 유산균포집 미분의 미분 첨가량이 $10 \%$ 에서 $50 \%$ 로 높아질수록 각각 $168.29^{\circ} \mathrm{C}, 174.54^{\circ} \mathrm{C}$, $177.77^{\circ} \mathrm{C}$ 및 $180.80^{\circ} \mathrm{C}$ 로 높아지는 경향을 나타내어 amyloselipid complex의 용융이 많이 일어나는 것으로 사료된다. DSC thermogram상의 흡열엔탈피를 전분이 호화될 때 나타 나는 엔탈피로 볼 때(35), 호화에 필요한 흡열 엔탈피는 높아지는 경향을 나타내었는데 특히 유산균포집 미분의 미분 첨가량이 $30 \%$ 및 $50 \%$ 의 경우 각각 $196.2 \mathrm{~J} / \mathrm{g}$ 및 199.4 $\mathrm{J} / \mathrm{g}$ 으로 높게 나타났다.

Table 3. Differential scanning calorimeter of rice flour that included Lactobacillus plantarum CGKW3 by a spray-drying process

\begin{tabular}{ccccc}
\hline Samples ${ }^{1)}$ & $\begin{array}{c}\mathrm{T}_{0}^{2)} \\
\left({ }^{\circ} \mathrm{C}\right)\end{array}$ & $\begin{array}{c}\mathrm{T}_{\mathrm{p}}^{2)} \\
\left({ }^{\circ} \mathrm{C}\right)\end{array}$ & $\begin{array}{c}\mathrm{T}_{\mathrm{c}}^{2)} \\
\left({ }^{\circ} \mathrm{C}\right)\end{array}$ & $\begin{array}{c}\Delta \mathrm{H}^{2)} \\
(\mathrm{J} / \mathrm{g})\end{array}$ \\
\hline Non & 24.84 & 97.01 & 177.39 & 191.8 \\
S10 & 25.22 & 89.26 & 168.29 & 128.9 \\
S20 & 25.22 & 97.90 & 174.54 & 172.0 \\
S30 & 25.22 & 99.01 & 177.77 & 196.2 \\
S50 & 24.47 & 103.77 & 180.80 & 199.4 \\
\hline
\end{tabular}

${ }^{1)}$ Non, spray-dried powder of $100 \%$ rice flour; S10, spray-dried powder of $10 \%$ rice flour included $L$. plantarum CGKW3; S20, spray-dried powder of $20 \%$ rice flour included $L$ plantarum CGKW3; S30, spray-dried powder of 30\% rice flour included L plantarum CGKW3; S50, spray-dried powder of 50\% rice flour included L plantarum CGKW3.

${ }^{2} \mathrm{~T}_{0}, \mathrm{~T}_{\mathrm{p}}, \mathrm{T}_{\mathrm{c}}$ indicate gelatinization onset, peak and completion temperatures, respectively; $\Delta \mathrm{H}$ is designated as gelatinization enthalpy.

\section{분무건조공정에 의한 유산균 포집특성}

분무건조공정에 의한 유산균 포집특성은 Table 4 와 같다. 유산균 포집특성을 검토한 결과 $10 \%$ 미분 첨가 시 $\mathrm{g}$ 당 $5.78 \log \mathrm{CFU}$ 로 가장 낮은 생균수를 나타내었으며, 특히 미분의 첨가량이 $10 \%$ 에서 $50 \%$ 로 높아질수록 각각 5.78 $\log \mathrm{CFU} / \mathrm{g}, 6.38 \log \mathrm{CFU} / \mathrm{g}, 6.69 \log \mathrm{CFU} / \mathrm{g}$ 및 $7.11 \mathrm{log}$ $\mathrm{CFU} / \mathrm{g}$ 로 높아지는 경향을 나타내었다. Choi 등(37)은 유산 균을 함유한 알긴산 미세입자 $(10 \mu \mathrm{m})$ 를 제조하여 유산균수 를 측정한 결과 $3.26 \times 10^{5} \mathrm{CFU} / \mathrm{g}$ 을 나타낸다고 보고하였으 며, Lee 등(38)은 유산균 미세캡슐(120 486 ㅆm)의 유산균수 를 측정한 결과 $\mathrm{pH} 2 \sim 4$ 의 낮은 $\mathrm{pH}$ 조건에서만 $1.2 \times 10^{7}$ $\mathrm{CFU} / \mathrm{g} 1.1 \times 10^{8} \mathrm{CFU} / \mathrm{g}$ 의 생균수를 나타낸다고 보고하였 다. 본 연구에서 $50 \%$ 미분을 첨가한 유산균포집 미분의 경우 $7.11 \log \mathrm{CFU} / \mathrm{g}$ 의 유산균을 포집하면서 입자크기는 $131.17 \mu \mathrm{m}$ 로 미세캡슐의 제조가 가능하여 다양한 식품에 적용이 가능하고 식품산업에 활용가치가 높을 것으로 판단 된다. 유산균 24시간 배양액 $(9.63 \log \mathrm{CFU} / \mathrm{mL}$ )과 비교한 유산균 생존율의 경우, 미분의 첨가량이 $10 \%$ 에서 $50 \%$ 로 높아질수록 유산균 생존율이 각각 $60.02 \%, 66.25 \%, 69.47 \%$ 및 $73.85 \%$ 로 유의적으로 높아지는 것을 확인할 수 있었다. 특히 유산균포집 미분의 첨가량이 $50 \%$ 의 경우 유산균 생존 율이 $73.85 \%$ 로 나타나 높은 안정성을 나타내었으며, 이를 통해 기능성이 향상된 유산균포집 미분을 제공할 수 있을 것으로 판단된다. 유산균수의 경우 $\mathrm{pH}$ 및 산도가 유산균수 를 확인하는 중요한 지표로 보고되고 있는데, 유산균포집 미분의 경우 유산균수가 높아질수록 $\mathrm{pH}$ 는 높아지고, 산도 는 낮아지는 경향을 나타내었다. $\mathrm{pH}$ 는 유산균을 첨가하지 않은 미분의 경우 $\mathrm{pH}$ 6.78로 나타나 가장 높은 값을 나타내 었으며, 유산균포집 미분의 경우 미분의 첨가량에 따라 $\mathrm{pH}$ 4.04 4.11로 나타냄을 확인하였다. 이와같이 미분에 유산 균을 포집하였을 경우 낮은 $\mathrm{pH}$ 로 인해 저장안정성이 향상

Table 4. Viable cell count, $\mathrm{pH}$, and acidity of rice flour that included Lactobacillus plantarum CGKW3 by a spray-drying process

\begin{tabular}{ccccc}
\hline \multirow{2}{*}{ Samples ${ }^{1)}$} & \multicolumn{2}{c}{ Viable cell count } & \multirow{2}{*}{$\mathrm{pH}$} & $\begin{array}{c}\text { Acidity } \\
(\%)\end{array}$ \\
\cline { 2 - 3 } & $\log$ CFU/g & $\%^{2)}$ & & $6.78 \pm 0.02^{\mathrm{a}}$ \\
\hline Non & - & - & $\mathrm{ND}^{4)}$ \\
S10 & $5.78 \pm 0.24^{\mathrm{d} 3)}$ & $60.02 \pm 2.53^{\mathrm{d}}$ & $4.04 \pm 0.01^{\mathrm{c}}$ & $0.72 \pm 0.01^{\mathrm{a}}$ \\
S20 & $6.38 \pm 0.09^{\mathrm{c}}$ & $66.25 \pm 0.97^{\mathrm{c}}$ & $4.04 \pm 0.00^{\mathrm{c}}$ & $0.56 \pm 0.04^{\mathrm{b}}$ \\
S30 & $6.69 \pm 0.18^{\mathrm{b}}$ & $69.47 \pm 1.90^{\mathrm{b}}$ & $4.05 \pm 0.01^{\mathrm{c}}$ & $0.42 \pm 0.01^{\mathrm{c}}$ \\
S50 & $7.11 \pm 0.15^{\mathrm{a}}$ & $73.85 \pm 1.55^{\mathrm{a}}$ & $4.11 \pm 0.01^{\mathrm{b}}$ & $0.31 \pm 0.01^{\mathrm{d}}$ \\
\hline
\end{tabular}

${ }^{1)}$ Non, spray-dried powder of $100 \%$ rice flour; S10, spray-dried powder of $10 \%$ rice flour included $L$. plantarum CGKW3; S20, spray-dried powder of $20 \%$ rice flour included $L$ plantarum CGKW3; S30, spray-dried powder of $30 \%$ rice flour included $L$ plantanum CGKW3; S50, spray-dried powder of 50\% rice flour included L. plantarum CGKW3.

${ }^{2)} \%$ of culture medium on $L$. plantarum $\mathrm{CGKW}$.

${ }^{3}$ Means \pm SD ( $n=3$ ) within each column (a-d) followed by the same letter are not significantly different $(\mathrm{p}<0.05)$.

${ }^{4)}$ Not detected. 
될 것으로 판단되며, 추가적인 연구가 필요하다고 사료된다.

이와 같이 분무건조에 의한 유산균포집 미분을 제조하여 품질특성 및 유산균 생존율을 측정한 결과 유산균 배양액에 $50 \%$ 의 미분을 첨가한 유산균포집 미분에서 높은 물리화학 적 특성을 나타내었으며, 특히 유산균 생존율이 높게 나타 나 쌀 가공제품 개발시 기능성 및 가공적성이 향상된 미분 의 제조 및 품질개선을 위한 기초 자료로 활용가능하다 판단된다.

\section{요 약}

본 연구에서는 국내 쌀의 소비를 증가시키고 쌀 가공제 품 개발시 기능성 및 가공적성이 향상된 미분을 제공하고자 분무건조공정에 의해 유산균을 포집한 미분을 제조하였으 며 유산균포집 미분의 품질특성 및 유산균 생존율을 조사하 였다. 유산균포집 미분의 제조는 미분을 24시간 배양한 유 산균 배양액 대비 각각 $10 \%, 20 \%, 30 \%$ 및 $50 \%(\mathrm{w} / \mathrm{v})$ 을 첨가 하여 분무건조하였다. 유산균포집 미분의 아밀로오즈함량 및 손상전분함량은 각각 $14.18 ~ 17.75 \%$ 및 24.65 34.08\%이 었다. 유산균포집 미분의 입자크기는 82.28 131.17 $\mu \mathrm{m}$ 로 미세캡슐로 제조되었음을 확인하였으며, 전반적으로 구형 의 모양을 보여주어 분말 흐름성이 양호할 것으로 판단된 다. 수분함량의 경우 유산균을 첨가하지 않은 미분(3.34\%) 에 비하여 유산균포집 미분이 2.32 2.62\%로 유의적으로 낮은 함량을 나타내었으며, 수분흡수지수 및 수분용해지수 측정결과 유산균포집 미분제조시 흡습성이 낮고 용해성이 양호한 분말을 얻을 수 있을 것이라 판단된다. 시차주사열 량계에 의한 호화특성을 측정한 결과 유산균포집 미분에서 호화에 필요한 호화엔탈피가 높아 취반 특성이 높을 것으로 사료된다. 유산균포집 미분의 유산균 포집특성을 확인한 결과, 미분의 첨가량이 높아질수록 $60.02 ~ 73.85 \%$ 로 유의적 으로 높은 유산균 생존율을 보여주어 높은 안정성을 나타내 는 것으로 확인되었다. 특히, $50 \%$ 미분을 첨가한 유산균포 집 미분의 유산균수, $\mathrm{pH}$ 및 산도는 각각 $7.11 \log \mathrm{CFU} / \mathrm{g}$, $\mathrm{pH} 4.11$ 및 $0.31 \%$ 이었으며, 이를 통해 기능성이 향상된 유산균포집 미분을 제공할 수 있을 것으로 판단된다. 따라 서 분무건조공정을 이용한 유산균포집 미분은 쌀 가공제품 개발시 기능성 및 가공적성이 향상된 미분의 제조가 가능하 고 유산균 안정성이 우수하여 기능성 식품 소재 개발에 있어 산업적으로 적용 가능할 것으로 사료된다.

\section{감사의 글}

본 연구는 산업통상자원부에서 지원하는 2014년도 지역 특화산업육성 기술개발사업(No.R0002973)의 연구수행으
로 인한 결과물임을 밝힙니다.

\section{References}

1. Ahn GN, Lee WW, Jeon YJ (2014) Effect of different molecular weights of chitosans on the growth of lactic acid bacteria from the traditional fermented foods. J Chitin Chitosan, 19, 194-200

2. Marteau PR, De Vrease M, Cellier CJ, Schrezenmeir J (2001) Protection from gastointestinal diseases with the use of probiotics. Am J Clin Nutr, 73, 430-436

3. Kim JY, Park BK, Park HJ, Park YH, Kim BO, Pyo $S$ (2013) Atopic dermatitis mitigating effects of new Lactobacillus strain, Lactobacillus sakei probio 65 isolated from Kimchi. J Appl Microbiol, 115, 517-526

4. Gueimonde M, Senchez B (2012) Enhancing probiotic stability in industrial processes. Microb Ecol Health Dis, $23,2-5$

5. Marteau P, Minekus M, Havenaar R, Huis JHJ (1997) Survival of lactic acid bacteria in a dynamic model of the stomach and small intestine : validation and the effects of bile. J Dairy Sci, 80, 3031-3037

6. Walker WA, Duffy LC (1998) Diet and bacterial colonization : role of probiotics and prebiotics. J Nutr Biochem, 9, 668-675

7. Graves RE (1972) Uses for microencapsulation in food additives. Cereal Sci, 17, 107

8. Reineccius GA (1995) Controlled release techniques in the food industry. In : Encapsulation and controlled release of food ingredients, Risch SJ, Reineccius GA (Editor), American Chemical Society, Washington, DC, USA, p 8-25

9. Shahidi F, Han XQ (1993) Encapsulation of food ingredients. Crit Rev Food Sci, 33, 501-547

10. King AK (1995) Encapsulation of food ingredients. A review of available technology, focusing on hydrocolloids. In : Encapsulation and controlled release of food ingredients, Risch SJ, Reineccius GA (Editor), American Chemical Society, Washington, DC, USA, p 26-41

11. Young RA (1986) Spray drying encapsulation-today's view. Ingred Proc Packaging, 31, 34-38

12. Jackson LS, Lee K (1991) Microencapsulation and the food industry. Lebensm-wiss Technol, 24, 289-297

13. Korus J, Tomasik P, Lii CY (2003) Microcapsules from starch granules. J Microencapsul, 20, 47-56

14. Ahn JY, Ha TY (2010) Nutritional superiority of Korean 
rice. Food Preserv Process Ind, 9, 60-64

15. Hong YH, Ahn HS, Lee SK, Jun SK (1988) Relationship of properties of rice and texture of Japonica and Indica rices of different amylose content. Korean J Crop Sci, 53, 285-291

16. Kem JS (1998) Effects of amylose content on quality of rice bread. Korean J Food Sci Technol 30, 590-595

17. Chen JJ, Lu S, Lii CY (1999) Effect of milling on the physicochemical characteristics of waxy rice in Taiwan. Cereal Chem, 76, 796-799

18. Chiang PY, Yeh AI (2002) Effect of soaking on wet milling of rice. J Cereal Sci, 35, 85-94

19. Statistics Korea (2015) Food grain consumption survey report. Korea, p 31

20. Lee NY (2013) Starch and quality characteristic of Korean rice cultivar with waxy and non-waxy type. Koran J Crop Sci, 58, 226-231

21. Jun HI, Yang EJ, Kim YS, Song GS (2008) Effect of dry and wet milling on physicochemical properties of black rice flours. J Korean Soc Food Sci Nutr, 37, 900-907

22. Kim WS, Shin M (2007) The properties of rice flours prepared by dry and wet milling of soaked glutious and normal grains. Korean J Food Cookery Sci, 23, 908-918

23. Han SH, Rho JO (2009) Quality characteristics of Sulgiddeok with different commercial rice flours. Korean J Food Nutr, 22, 402-408

24. Lee MH, Lee YT (2006) Bread-making properties of rice flours produced by dry, wet and semi-wet milling. J Korean Soc Food Sci Nutr, 35, 886-860

25. Han HM, Cho JH, Koh BK (2011) Processing properties of Korean rice varieties in relation to rice noodle quality. Food Sci Biotechnol, 20, 1277-1282

26. Yang SC, Lee I, Sun JH, Kim DE, Kang WS, Chung HS, Shin M, Ko S (2010) Development of wellreconstituted instantized thin rice grauel. Food Engineering Process, 14, 54-59

27. Hur S, Cho S, Kum JS, Park JW, Kim DS (2011) Rice flour-a functional ingredient for premicum crabstick.
Food Sci Biotechnol, 20, 1639-1647

28. Williams PC, Kuzina FD, Hlynka I (1970) A rapid colorimetric method for estimating the amylose content of starches and flours. Cereal Chem, 47, 411-421

29. Boyaci IH, Williams PC, Koksel H (2004) A rapid method for the estimation of damaged starch in wheat flours. J Cereal Sci, 39, 139-145

30. Phillips RD, Chinnan MS, Granch AI, Miller J, Mcwatters $\mathrm{KH}$ (1998) Effects of pretreatment on functional and nutritional properties of cowpea meal. J Food Sci, 53, 805-809

31. Kim HS, Huber KC (2010) Physicochemical properties and amylopectin fine structures of A- and B-type granules of waxy and normal soft wheat starch. J Cereal Sci, 51, 256-264

32. Han HM, Cho JH, Koh BK (2012) Effect of grinding method on flour quality in different rice cultivars. J Korean Soc Food Sci Nutr, 41, 1596-1602

33. Park JD, Choi BK, Kum JS, Lee HY (2006) Physicochemical properties of brown rice flours produced under different drying and milling conditions. Korean J Food Sci Technol, 38, 495-500

34. Jeong JW, Park KJ, Kim MH, Kim DS (2006) Changes in quality of spray-dried and freeze-dried Takju powder during storage. Korean J Food Sci, 38, 513-520

35. Choi ID (2010) Fatty acids, amino acids and thermal properties of specialty rice cultivars. J Korean Soc Food Sci Nutr, 39, 1405-1409

36. Ko JH, Park KH (1989) Differential scanning calorimetric study of amylose-lipid complex and amylose content in rice starch. Korean J Food Sci Technol, 21, 556-561

37. Choi CY, Kang SK, Park SK, Jang MK, Nah JW (2007) Preparation and characterization of lactic acid bacteria encapsuled with alginate microsphere. J Life Sci, 17, 1754-1759

38. Lee KW, Jang KI, Lee YB, Sohn HS, Kim KY (2007) Development of probiotic microcapsules for the preservation of cell viability, Korean J Food Sci Technol, $39,66-70$ 